\title{
Social ecosystem health: confronting the complexity and emergence of infectious diseases
}

\author{
Saúde no ecossistema social: \\ enfrentando a complexidade e a emergência \\ de doenças infecciosas
}

Cristina de Albuquerque Possas 1

\footnotetext{
1 Vice-presidência de Tecnologia, Fundação Oswaldo Cruz. Av. Brasil 4365, Rio de Janeiro, $R J$ 21045-900, Brasil. cpossas@netra.castelo.fiocruz.br
}

\begin{abstract}
The emergence and re-emergence of infectious diseases and their rapid dissemination worldwide are challenging national health systems, particularly in developing countries affected by extreme poverty and environmental degradation. The expectations that new vaccines and drugs and global surveillance would help reverse these trends have been frustrated thus far by the complexity of the epidemiological transition, despite promising prospects for the near future in biomolecular research and genetic engineering. This impasse raises crucial issues concerning conceptual frameworks supporting priority-setting, risk anticipation, and the transfer of science and technology's results to society. This article discusses these issues and the limitations of social and economic sciences on the one hand and ecology on the other as the main theoretical references of the health sciences in confronting the complexity of these issues on their own. The tension between these historically dissociated paradigms is discussed and a transdisciplinary approach is proposed, that of social ecosystem health, incorporating these distinct perspectives into a comprehensive framework.
\end{abstract}

Key words Ecosystem; Infectious Diseases; World Health; Ecology

Resumo A emergência e reemergência de doenças infecciosas e sua rápida disseminação em escala global estão desafiando os sistemas nacionais de saúde, em particular nos países em desenvolvimento afetados pela pobreza extrema e pela degradação ambiental. As expectativas de que novas vacinas e medicamentos e a vigilância global contribuiriam para impedir essas tendências têm sido até aqui frustradas pela complexidade da transição epidemiológica, em que pese às perspectivas promissoras da biologia molecular e da engenharia genética. Esse impasse levanta questões cruciais relacionadas às estruturas conceituais que embasam a definição de prioridades, a antecipação de riscos e a transferência dos resultados da ciência e da tecnologia para a sociedade. Este artigo discute essas questões e as limitações das ciências sociais e econômicas, de um lado, e da ecologia, de outro, como principais referências teóricas das ciências da saúde, para enfrentar sozinhas a complexidade desses cenários. A tensão entre esses paradigmas historicamente dissociados é discutida, e uma abordagem transdisciplinar é proposta - ecossistema social e saúde -, incorporando essas distintas perspectivas em um referencial teórico abrangente.

Palavras-chave Ecossistema; Doenças Infecciosas; Saúde Mundial; Ecologia 


\section{Introduction}

In the contemporary world, infectious diseases are still the main causes of death, killing more people than heart disease or cancer. Their incidence and spread have increased in the last two decades, although scientists and policymakers in the 1960s believed they could be kept "under control" by development, sanitation, new medical technologies, and advances in the pharmaceutical industry. The unexpected phenomena of emergence and re-emergence of infectious diseases and drug-resistant diseases, whose incidence is increasing rapidly, will certainly change the global epidemiological scenario in the near future.

Various social and ecological processes, such as extreme poverty, population movements, urbanization, and deforestation, favor the emergence and resurgence of infectious syndromes and diseases and increase their epidemiological complexity. The intensification of international travel and migration has also helped amplify these processes, accelerating the movement of humans, animals, and plants and the global proliferation of viruses, bacteria, and fungi.

Globalization, resulting in the rapid incorporation of new technologies and amplifying the impacts of urbanization, unemployment, social exclusion, and poverty, aggravates the consequences of these social and ecological changes in ways never before imagined (Levins et al., 1986).

These changing conditions favor the global emergence and resurgence of various infectious diseases with complex and dynamic cycles, such as HIV/AIDS, tuberculosis, dengue, yellow fever, malaria, leishmaniasis, leptospirosis, hantavirus pulmonary syndrome, and many others. The rapid spread of these diseases worldwide challenges national health systems, particularly affecting developing countries like Brazil, a nation plagued by social exclusion and environmental degradation and with a rapidly aging population.

In these developing countries, social and ecological processes are often interconnected. In the early 20th century, developing countries harbored a large proportion of the world's preserved forest ecosystems, i.e., the tropical forests. Nevertheless, as a consequence of various predatory interventions, large areas of these preserved forests have become complex urban ecosystems, affected by a broad range of social and economic processes related to the industrialization and modernization of agriculture in the agro-industries.

In Brazil, the detrimental impacts of these economic activities on the Amazon Forest, the
Atlantic Forest, and the cerrado (savanna) are evident. Various development projects have stimulated deforestation, erosion, floods, and population flows into these ecosystems, creating new villages in forest areas. Such changes have involved the introduction of humans into ecological niches, amplifying the risks of exposure to pathogens formerly confined to animals, such as yellow fever flavivirus (monkeys) and hantavirus (rodents).

Global warming, only recently an accepted hypothesis, despite evidence of the environmental impact of human intervention and pollution, also amplifies the risks brought about by these social and ecological changes resulting from deforestation. It stimulates the flow of disease vectors (mosquitoes, ticks, and others) from tropical to temperate zones. These new scenarios increasingly concern developed nations, which had previously played down the importance of "tropical" infectious diseases, assumed to be restricted to the poorest countries.

This article examines the possible epidemiological scenarios resulting from these phenomena and the limitations of the social and economic sciences and ecology to deal with their complexity. The tension between these historically dissociated paradigms is discussed and a transdisciplinary approach is proposed, i.e., social ecosystem health, in order to incorporate them into a comprehensive theoretical framework, supporting alternative strategies to anticipate risks and prevent the amplification of risk conditions (Levins et al., 1994, 1995; Possas \& Marques, 1994; Levins \& Lopez, 1999).

In this approach, anticipation of risks and interventions should be examined simultaneously from a social sciences perspective, as social and political processes, and from an ecological perspective, as an evolutionary force in ecosystems. Contrary to common sense, evolution can be affected by social and health policies, since the time scales in evolutionary processes are not necessarily large or even secular. Natural selection can be fast, as an expression of evolutionary plasticity in the evolution among pathogens, and can be influenced by intervention (Levins, 1994; Levins et al., 1994, 1995).

\section{Emergence: epidemiological complexity}

The notion of emergence is crucial to understanding biological phenomena and requires an adequate theoretical framework. Emergence results from possible new properties in a complex system which are not reducible to the sys- 
tem's simple constituent elements. Recognition of emerging properties in complex systems allows scientists to overcome the reductionism in simplistic and stereotyped approaches to the scientific method.

As Prigogine \& Stengers (1984) and Kauffman (1993) have pointed out in discussing the phenomenon of order emerging from chaos, the notion of self-organization in complex systems is related to the concept of emergence. This concept highlights the limitations of a certain view of science, supported by predictive capacity and reductionism. In the particular case of models called chaotic, in non-linear systems of equations, small changes in parameters and/or in initial conditions can result in dramatic consequences in the final outcomes, including unpredictability. In previous publications, in a model we developed to examine the Brazilian epidemiological profile (Possas, 1989, 1992; Levins et al. 1993), small changes in social and economic conditions led to dramatic changes in the final outcome, i.e., the population's health profile.

The notion of complexity is thus at the core of modern biology and is crucial for understanding phenomena related to the emergence of pathogens and diseases. However, since most biological processes related to emergence and re-emergence of pathogens and diseases are triggered by environmental change and human activity, in order to approach their complexity it is necessary to deal with complexity in other areas of knowledge: complex social and economic systems, as shown by Hodgson (G. M. Hodson: personal communication) and Whitehead (1993), and complex ecosystem health (Rapport, 1989; Levins et al., 1994, 1995; Waltner-Toews, 1996).

However, the main challenge here is how to bridge the disciplinary gaps between social and economic sciences and ecology in order to provide a better understanding of the complex interactions linking human populations, social organizations, and the environment.

Emerging and re-emerging infectious diseases have been defined (Lederberg et al., 1992) as diseases whose pathogenic agents are unknown or unexpected or whose incidence has increased in the last two decades. Re-emergence has been defined as the resurgence of a known disease after a significant decline in its incidence. Despite some differences in labeling pathogenic agents, syndromes, or diseases as new, emerging, or re-emerging, there is a reasonable consensus among international agencies (World Health Organization - WHO -, PanAmerican Health Organization - PAHO) and national governments in this area.
Nevertheless, in order to avoid unacceptable mistakes, it is important to stress at the conceptual level that these definitions should not be restrictive.

On the one hand, concerning new or emerging diseases, as we have noted in previous publications (Levins et al., 1995), most bacteria are not pathogenic, most arthropods are not disease vectors, and most mammals do not cause disease in humans. If they emerge as a cause of disease, this often results from environmental change and human activity favoring the amplification of risk conditions. Practically all pathogens defined as "new" existed previously in nature and in most cases have not changed their genetic structure. Their emergence as "new" agents has resulted from significant changes in social and environmental conditions favoring their access to new host populations or the increase of their virulence in immune-compromised hosts. Pathogens previously confined to monkeys (yellow fever) or rodents (hantavirus) moved into human populations because human activities created the opportunity for them to do so.

On the other hand, concerning re-emerging diseases, it is important to note that endemic diseases or pathogenic agents not defined as new, emerging, or re-emerging, which persist without significant changes in their behavior, should not be viewed as "stable" or labeled as "persistent", "unchangeable", or "remaining". Such a view would mean to assume a stability of viruses, bacteria, and fungi that does not exist in nature.

On the contrary, these microbes are exposed to selective pressure that does not always occur in the long term. Contradicting intuitive arguments, the time scales in evolutionary processes are not necessarily large or even secular. The development of multidrug resistant bacteria in hospitals is a good example. Natural selection can happen very rapidly, as an expression of evolutionary plasticity in the evolution among pathogens. For this reason, diseases assumed to be endemic or "stable" are rapidly changing their pattern of dissemination.

Therefore, a disease now assumed to be "endemic" or "remaining" can escape control and become a re-emerging disease in the near future. A good example is yellow fever, eradicated from Brazilian urban areas since 1942 and confined to its sylvatic pattern of dissemination in ecological niches by Haemagogus mosquitoes circulating the Flavivirus arbovirus among monkeys. Recently, penetration of humans into these niches by deforestation, farming, and ecological tours has introduced sylvat- 
ic yellow fever patients into the main Brazilian urban areas, already exposed to the Aedes aegypti mosquitoes transmitting dengue. Therefore, there is a significant risk of urbanization of yellow fever in Brazil - according to Silveira (1998), estimated number of cases is ten times that of reported cases -, despite the availability of a high quality vaccine - Brazil's Fundação Oswaldo Cruz (FIOCRUZ) produces $70 \%$ of the world's yellow fever vaccine - and lasting immunity, estimated at ten years. Another example is dengue, formerly eradicated and now disseminated and a major public health concern in Brazil, since there is no vaccine available and there is a real risk of hemorrhagic dengue fever epidemics. Finally, malaria has become resistant to several drugs and poses an important challenge in the Amazon region.

Social and economic changes have aggravated this epidemiological complexity and favored the resurgence of these infectious diseases. On the one hand, there has been mass migration to urban areas lacking adequate infrastructure. On the other, urban populations, especially the poor, are crowded into peripheral metropolitan areas and are increasingly penetrating into previously preserved ecosystems to eke out a living. Consequently, ecosystems like the Amazon, the Atlantic Forests, and the cerrado (savanna) are increasingly being integrated into complex urban ecosystems by social and economic processes in both metropolitan areas and nearby small urban villages.

We have discussed in previous publications how changes in society and in ecosystems that lead to population mobility and environmental degradation can exert selective pressure on pathogenic agents, increasing the plasticity of known strains of bacteria and viruses, favoring the emergence and resurgence of infectious diseases worldwide. We have examined how multiple infections from diverse origins, recombining and producing new strains of pathogens, also contribute to increased plasticity by creating conditions for recombination and production of new strains of pathogens (Epstein et al., 1994; Levins, 1994; Levins et al. 1994, 1995).

The impact of intervention can also favor the emergence or resurgence of infectious diseases. Antibiotics can increase infection and resistance. Extensive use of pesticides and other chemical products against vectors of infectious diseases may change patterns in the interactions between predator and prey. When we eliminate the natural enemies, we are creating new ecological niches for the animals we intend to eliminate. When we kill vectors of diseases without taking the specific local con- ditions of ecological balance into account, we may favor the survival and reproduction of more resistant strains and populations. When we kill mosquitoes with larvicides we can create more resistant species, increasing their vectorial capacity (Levins et al., 1993, 1994, 1995; Levins, 1994). We may also kill frogs feeding on mosquito larvae and favor the proliferation of more resistant mosquitoes in new areas. When we kill one rodent species in an area without eliminating the waste on which rodents feed, a new species can take the place of the former and continue to transmit the disease.

Therefore, social response to epidemics and public health interventions should be understood not only from a social sciences perspective, as social and political processes, but as suggested by Levins (1994), from an ecological perspective, as an evolutionary force and a component of the evolutionary process, interfering directly in it. When the prevalence or incidence of a disease increase in a society, diverse behavioral and institutional changes in public health are usually triggered. Such new behaviors and intervention patterns often help change the conditions of contagion and accelerate diagnosis and treatment. This social response affects vector populations and habitats, since it expresses crucial behavioral and intervention patterns in society that can be considered, according to the author, as "co-parameters in the same sense of the reproduction rates of pathogens or rates of frequency of mosquito bites or the duration of immunity".

Political issues and equity are thus not only issues of social justice. As proposed by Levins (1994), they interfere directly in the evolutionary process, since they refer to the specific conditions of social response to pathogens. Multiple interactions between variables in the contexts of variation, selection, and the impact of selection on diverse species communities and health intervention should be considered. The epidemiological complexity requires a transdisciplinary approach that transcends common sense and reductionism. Therefore, in order to understand and confront the evolution of pathogenic systems it is necessary to conceive a new social ecosystem health perspective.

\section{Ecosystem and society: disciplinary boundaries}

The limitations of each respective disciplinary field in confronting, by itself, the complexity and emergence of pathogens and diseases are evident and result from the historical dissocia- 
tion of different paradigms, building separate theoretical frameworks and methodologies and thus restricting future scientific and technological development in this area.

Besides this difficulty in integrating diverse conceptual references into a common academic structure, it should be noted that both fields have developed their frameworks in more stable settings: the rapid changes resulting from globalization have spawned perplexity and adherence to tradition, contributing to the persistence of the gap, despite several important transdisciplinary initiatives. On the one hand, social and economy theories tend to minimize the environment and the biosphere, focusing on health care reforms; on the other, ecologists tend to misunderstand the social and economic forces driving or restraining their actions, focusing on local sustainability and the ecological impacts of interventions.

The complexity of the phenomena resulting in emergence and re-emergence of infectious diseases requires a new transdiciplinary approach - social ecosystem health. In a recent publication, Levins \& Lopez (1999) provide important insights in this direction, emphasizing the need for an ecosocial view of health.

\section{Ecosystem health and emergence: metaphorical thought}

Several authors have debated the status of ecosystem health: concept, notion, or metaphor? Gallopín (1994), in his article on the status of ecosystem health in agriculture (agro-ecosystem health), comments that it is not so clear if this approach can become the much-needed framework for "an accepted research model which embraces the physical, biological, and human dimensions of long-term sustainability" (CGIAR, 1993:8). He calls attention to the ambiguity of the concept of ecosystem health, which according to him "gives it some of its richness" and concludes that "it might well be that the concept is more useful as a metaphor suggesting more systematic approaches to the diagnosis and treatment of agrecosystems ills, underscoring the importance of validation of remedial action interventions..." (Gallopin, 1994:59).

Various authors have discussed whether ecosystem health in socioecological systems can be understood in this metaphorical sense. Ecosystems are often viewed as concrete representations of food chains, where system elements evolve and co-evolve and species collaborate and compete in complex cycles: predators, prey, hosts, and parasites.
As Lakoff \& Johnson (1980) pointed out in their classic book, most abstract thoughts are metaphorical, since they use concrete ideas to reason about less concrete ones, often unconsciously. Their book on cognitive science, approaching linguistics and philosophy of sciences, was the first organized exploration on metaphors and how they affect both our world view and our unconscious thought processes.

As indicated by Habermas (1991), the split between an omnipresent "system" and "lifeworld" (everyday social knowledge) indicates why it is so difficult for philosophers and scientists to assume a broad and transcendent epistemological perspective and bridge the gaps between "system", "society", "health", and "ecology".

Morin (1983) noted this problem in his attempt to articulate man/animal and nature/ culture, not by reduction of the former to the latter, but by complexifying both. But, according to him, this demonstration had little effect: "the great disjunction (bios/anthropos) and the great reduction (from complex to simple) continue to reign undisturbed in our universities" (Morin, 1983:385).

Another epistemological constraint is that postmodernists - and many ecologists and social scientists share this view - emphasize postindustrial information or knowledge society as the new societal formation, and their theoretical formulations are based on incredulity toward the possibility of metadiscourses or metanarratives, which have lost their credibility (Lyotard, 1984). In this sense, postmodernism tends to reject comprehensive social theories or broad epistemological perspectives. This context has favored the hegemony of relativism in the sociology of science and of a social constructivism opposing "social" and "natural" and overestimating the cultural and cognitive aspects of science.

As noted by Cole (1992), "nature poses some strict limits on what the content of a solution adopted by the scientific community can be. By leaving nature out, the social constructivists make it more difficult to understand the way in which the external world and social processes interact in the development of scientific knowledge" (Cole, 1992:26).

In this widespread postmodern perspective, reality “...intrinsically cannot make sense or else only makes sense when remythologized on the basis of illusion and/or power struggles (...). Our only legitimate options are to simply accept disorder and uninterpretalibility (of life and culture) or to make highly contingent, local, and ultimately only weakly defensible efforts to bring order to a small part of the world" (Calhoun, 1995:112). 
The increasing yearning, in academic communities, for all forms of empirical representation, undervaluing theory, certainly reflects these recent trends. Hence, local geographic representation of reality and corresponding technologies (Geographical Information System - GIS -, mapping, spatial analysis) or local representation of perceptions or cultural values of specific communities (psychological and anthropological empirical studies) often become more important for scientists than understanding structural processes.

Concerning this increasing emphasis on representation, Calhoun (1995) notes that "in such a postmodern society the sign becomes the autonomous source and form of value, the signifier is detached from the signified. The structure of relations that now matters is not that by which capital dominates labor, or centers of power grow and eliminate the territorial organization of power. Rather, the structure of relations which now matters is among signs" (Calhoun, 1995:102).

It is in this postmodern context of revalorization of the local, of perceptions, and of culture in everyday life that the emergence and reconstruction of metaphors - health promotion, prevention, community health, sustainability, and ecosystem health - should be understood.

Discussions on the possibilities and limitations of the "ecosystem health" metaphor should take into account this debate concerning postmodern relativism and social constructivism, since they refer to an attempt to understand complexity, emergence, and human diseases in their ecological and social contexts.

\section{Society, globalization, and emergence: structural thought}

Contrasting with postmodern relativism, several authors have pointed out the new forms assumed by capitalism and their impacts on social organizations, on natural environments, and on social life worldwide. They have discussed the spiraling of the globalization process and its increasing complexity and noted that capitalism in its recent form is quite distinct from the strictly regulated form that flourished worldwide from 1945 to 1980. Luttwak (1999), in his concept of "geo-economy", called these new features "turbo capitalism". In his view, the main characteristic distinguishing "turbo capitalism" from the formerly regulated capitalism is the global introduction of an accelerated structural change and its simultaneously cre- ative and destructive potential, producing in spiraling and increasing speed both "more creation and more destruction, more efficiency and more inequality" (Luttwak, 1999:187).

According to this approach, the main consequence of this new form of capitalism in the political sphere is the shift of power from public authorities to private and institutional economic interests. Inevitably, these processes have drastically reduced the sphere of democratic control and regulation by society - and particularly by more vulnerable populations in developing countries - over destructive economic processes, thereby hindering the reduction of their traumatic impact on the lives of individuals, families, neighborhoods, cities, and nations. The natural environment and the social environment both become more vulnerable with the acceleration of these destructive impacts.

In fact, the indicators provided by the recent UNDP Human Development Report (UNDP, 1999) highlighted the social and economic impacts of globalization in terms of the inequity and vulnerability resulting from lack of social control and adequate regulation over concentration trends, which are rapidly aggravating social disparities worldwide. The report's main conclusion is that competitive markets can provide efficient production but cannot provide human development. Therefore, a new approach to global institutions and government is necessary.

Globalization has also accelerated detrimental impacts on the environment. The latest United Nations report, Global Environment Outlook 2000, indicates that since the Earth Summit in Rio eight years ago the same environmental trends have continued in most countries of the world and indicators have gotten even worse (UNEP, 2000). Significant increases in land degradation, forest loss, biodiversity loss, degradation of marine and coastal zones, atmospheric and water pollution, urban and industrial contamination, and waste were observed.

These drastic changes in the global scenario raise several issues concerning the nature of health reforms, particularly in more vulnerable developing countries, affected by the changing role of the state and shifting of power from the public sector to private and institutional economic interests. The reduction of democratic control and regulation by society over destructive economic processes is making it difficult to minimize the traumatic impact on the lives of individuals, families, and neighborhoods, affecting both society and the environment. 


\section{Social ecosystem health}

A social ecology of health (Levins \& Lopez, 1999) assumes that ecosystems are social ecosystems, increasingly transformed by human activity. This statement may sound obvious, and most ecologists would easily accept it. Nevertheless, it is not sufficient to introduce social and economic variables into the system or to involve local communities in system "management". Social and environmental interventions by ecologists as political actors are part of the system and interfere in its evolution.

Constanza (1994) properly synthesizes the need for an alternative approach: "The fundamental reason why we are so interested in ecosystem health is that we have got ourselves stuck or painted into a corner in managing ecosystems by the default criterion of having no human impact... What we are trying to do is to truly integrate science, policy, and management in dealing with ecosystems and moving beyond the no impact paradigm... We have to consider humans as components of ecosystems and we can no longer look for pristineness as the major criterion" (Constanza, 1994:29).

This debate raises issues concerning sustainability and sustainable development. According to some authors, the concepts of ecosystem health and sustainability are so closely related that for practical purposes they are essentially the same (Smit \& Smithers, 1994). Social and economic sciences have historically been incorporated into medicine and public health. However, there is an important gap in understanding the social and economic phenomena leading to emergence and re-emergence of pathogens and diseases.

In Latin America, important developments occurred in the last three decades in the fields of social epidemiology and social sciences in health, but few studies have focused on the complex conditions of emergence of specific diseases and pathogens.

Correspondingly, incorporation of new developments in contemporary ecology into public health and medicine is still limited. Several authors have contributed to this effort, but their contributions have still not been organized into a comprehensive framework.

Challenging these theoretical gaps, in many developing nations ecosystems are increasingly changing into complex urban ecosystems. McMullan (1998), extending the concept of researchers at the International Development Research Centre (IDRC) to the city, suggests that urban ecosystem health "is a concept encompassing the complex interplay among the environment and the social, economic, environmental, and political factors of a group of people living in a urban area (e.g., a city or neighborhood)" (McMullan, 1998:1).

In Brazil, diseases transmitted by insect and rodent vectors are being amplified by the changing social and ecological conditions in cities, in complex urban ecosystems. Leptospirosis is a good example. While in developed nations leptospirosis is a disease affecting mostly animals, in the main Brazilian cities approximately 3,600 patients are treated in hospitals every year for leptospirosis (annual average from 1991 to 1999) and a new pulmonary form of severe leptospirosis is emerging (Possas, 2000). The disease used to be a medical curiosity but is now disseminated as a result of faulty sanitation, waste, floods, and proliferation of the rodent transmitting the disease. In some areas, where local governments have succeeded in killing the rodent Rattus norvegicus transmitting icterohemorrhagic leptospirosis, other species of rodents, such as Rattus rattus, often take the former's place, since the lack of proper sanitation and waste disposal usually persist.

These theoretical and methodological difficulties in confronting a complex new reality certainly affect policy and decision-making to deal with emerging and re-emerging infectious diseases, particularly in developing countries suffering the consequences of globalization. These challenges can be examined from two different perspectives: risk anticipation and policy implementation. The first refers to the conditions for creating the necessary scientific and technological capacity to anticipate risk conditions and project scenarios for the future concerning emergence and re-emergence of pathogens, syndromes, and diseases in these countries. The second, based on adequate information on risk conditions, concerns the ability to implement effective intersectoral interventions, transferring existing knowledge and technologies to society. These issues are especially crucial for developing countries where structures for funding sciences and technology are often dissociated from health policy and decision-making.

\section{Eco-social models and future scenarios}

The incorporation of social and ecological variables into epidemiological models as a tool for anticipating and assessing impacts of environmental and social change on human populations has been widely recommended by international organizations and national govern- 
ments. Various quantitative and qualitative models have been developed with this purpose.

Nevertheless, several factors have restricted the utilization of population-based epidemiological models in policy and decision-making, especially in developing countries.

Such obstacles relate basically to three different issues: difficult access to information, since most of these countries lack adequate data on disease incidence and prevalence; lack of knowledge concerning population-based instruments and methodologies for epidemiological analysis; and inadequate conditions at the national and local levels to operate epidemiological analysis in the health and social planning processes.

Despite these constraints, predictive models can overcome the limitations of existing data and simulate scenarios for the future. Ecosocial models can provide valuable tools for these future scenarios, simulating alternatives to risk conditions and assessing the impacts of alternative environmental and social policies both at the national and local levels.

Eco-social models for emergence have been conceived from diverse approaches using both quantitative and qualitative mathematics (Puccia \& Levins, 1986; Puccia et al., 1994).

In former publications, some elements for an eco-social approach to epidemiological analysis were suggested. In a model developed to examine the epidemiological profile of the Brazilian population (Possas, 1989, 1992; Levins et al., 1993), we found that small changes in social and economic conditions lead to dramatic changes in the final outcome, i.e., the population's health profile. These results indicated an outcome similar to those produced by models of complexity called chaotic, in non-linear systems of equations, where small changes in parameters and/or in initial conditions can result in dramatic consequences in the final outcomes, including unpredictability.

This model proposed a non-conventional methodology, incorporating environmental and socioeconomic information related to risk factors for diseases. Risk conditions were identified from a review of the international literature on clinical epidemiology on risk factors for specific diseases. Information on socioeconomic and environmental conditions was obtained from national surveys for Brazil, which was selected as a country study for model simulation.

A predictive model for future studies on social and environmental impacts on health was conceived. It consists basically of six tables that do not require sophisticated statistical proce- dures, as an alternative approach to current biostatistical methods.

These six tables (population tables, risk tables, and epidemiological profile tables) are related to each other in such a way that the final outcome is the population's epidemiological profile. The scope of its extension can be defined at different levels: from local population studies to national ones.

The six tables are organized in two distinct sets: Tables 1, 2, and 3, where Table 3 is the result of Table 1 multiplied by Table 2 , and Tables 4,5 , and 6 , where Table 6 is the result of Table 4 multiplied by Table 5 . Table 1 is a given population's distribution according to each specific risk condition. Table 2 is the distribution of diseases according to each specific risk condition. Table 3 displays the population's epidemiological profile according to specific risk conditions. According to available data, it shows how incidence (or prevalence) and the respective time span are distributed in the total population and how they relate to each specific risk condition.

Table 4 is the population distribution according to all possible combinations of discrete levels/categories of risk conditions. It is an $\underline{n}$ dimension matrix, where $\underline{n}$ is the number of risk conditions considered. Table 5 is also a matrix of $\underline{\mathrm{n}}$ dimensions, where combined risk conditions are simultaneously related to a disease or diseases related to different conditions. Table 6, the total profile table, is the final product of Tables 4 and 5 and displays the total population's epidemiological profile as related to all possible combinations of risk conditions. Further analysis of these combinations should consider a specific hypothesis of cumulative effects, controlling confounding factors.

Since for most diseases there is no consensus on the effect of joint risk exposure, Spasof \& McDowell (1987) conclude that except for accidents (which experts assumed were best described by an additive model) and ischemic heart disease, for which they applied a logistic model, all other diseases were best described by a multiplicative model. A useful discussion of this methodological problem can be found in Gunning-Schepers (1989) resulting from her research on a simulation approach to prevention.

Finally, Table 6 is the final product of Tables 4 and 5 and displays the total population's epidemiological profile as related to all possible combinations of risk conditions.

To understand how these diverse risk conditions and diseases interact over a population demands a population-based approach rather than the disease-based approach characteristically used in clinical epidemiology. Neverthe- 
less, population-based eco-social models need the input of clinical epidemiology research to provide realistic prediction.

Eco-social models can indicate that in heterogeneous societies exposed to rapid social and ecological change it is often impossible to demarcate the diverse geographic and economic spaces where populations are now exposed to risks as "rural", "urban", or "sylvatic" areas or as either "archaic" or "modern" conditions. Rather, these life conditions overlap and have multiple effects. As a consequence, the same population is often exposed to diverse risk conditions, leading to complex epidemiological profiles as a result of the epidemiological transition.

\section{Conclusions}

The increasingly complex conditions of human populations' exposure and tolerance to the emergence and resurgence of pathogens and infectious diseases in the global context and the limitations of social and economic sciences on the one hand and ecology on the other to confront these new epidemiological scenarios by themselves highlight the urgent need for an alternative framework.

The expectations that new vaccines and drugs and global surveillance would help reverse the new epidemiological trends have been frustrated thus far by the increasing complexity of the epidemiological transition, despite promising prospects for the near future in biomolecular research and genetic engineering. As for new vaccines, the heavy social impact that these new developments (powerful new techniques such as DNA vaccines, peptides, new combinations of antigens, and conjugate vaccines) could have on human health contrasts with the enormous burden of vaccine-preventable diseases worldwide (Possas, 1996), aggravated by extreme poverty and environmental degradation. This impasse raises crucial issues concerning conceptual references for priority-setting, risk anticipation, and the transfer of science and technology's results to society.

This article has discussed the increasing tension between these historically dissociated paradigms and identified the need for a new transdisciplinary approach - social ecosystem health - incorporating these distinct perspectives into a comprehensive framework.

From the ecosystem perspective, the changing patterns of exposure, favoring new connections between the diverse chains of determina- tion, the causal and non-causal determinants, favor multiple conditions of vulnerability to the pathogens, affecting their biology in ecosystems increasingly transformed by human activity.

From the social sciences perspective, epidemiological complexity resulting from these new conditions requires a critical review of social and economic processes intensified by globalization and urbanization, which have blurred the traditional boundaries between global and local, urban and rural, with important theoretical and methodological implications.

The limitations of each disciplinary field to deal alone with the complexity and emergence of pathogens and diseases are evident and result from the historical dissociation of different paradigms, building separate theoretical frameworks and methodologies and thus constraining future scientific and technological developments in this area.

Besides this difficulty in integrating diverse conceptual references into a common academic structure, it should be noted that both fields have developed their frameworks in more stable settings: the rapid changes resulting from globalization has led to perplexity and adherence to tradition, contributing to the persistence of the gap, despite several important transdisciplinary initiatives. On the one hand, social and economic theories tend to minimize the environment and the biosphere, focusing on health care reforms; on the other, ecologists tend to misunderstand the social and economic forces driving or restraining their actions, focusing on local sustainability and the ecological impacts of interventions.

A social ecosystem health approach supported by a strong and continuous transdisciplinary effort can provide an alternative basis for a new theoretical framework and new methodologies, supporting eco-social strategies for specific surveillance of emerging and re-emerging infectious pathogens, syndromes, and diseases. These strategies, such as risk anticipation, modeling future scenarios, prevention, and health promotion, will require adequate priority-setting from governments and societies, along with the necessary investments in social policies, environmental policies, and science and technology, based on health information systems oriented to emergence. 


\section{Acknowledgments}

This article is an outcome of a research project on Emerging Diseases and Policy Strategies, in collaboration with Profs. Richard Levins and Tamara Awerbuch of the Harvard New Diseases Group, Department of Population and International Health, Harvard University School of Public Health. The Brazilian component of the research was funded by the National Research Council (CNPq) and by Fiocruz PAPES II Project. I thank Dr. Akira Homma, Fiocruz VicePresident for Technology, for the support provided to this project.

\section{References}

CALHOUN, C., 1995. Critical Social Theory. Oxford/ Cambridge: Blackwell Publishers.

CGIAR (Consultative Group for International Agricultural Research), 1993. The Ecoregional Approach to Research in the CGIAR. Report of the TAC/Centre Directors Working Group. San Juan: CGIAR.

COLE, S., 1992. Making Science: Between Nature and Society. Cambridge/London: Harvard University Press.

CONSTANZA, R., 1994. Supplementary Comments on the Concept of Ecosystem Health. In: International Workshop: Agriculture Health, Proceedings, pp. 29-30, Ottawa: University of Guelph/International Development Research Centre.

EPSTEIN, P.; FORD, T.; PUCCIA, C. \& POSSAS, C. A., 1994. Marine ecosystem health: Implications for public health. In: Disease in Evolution, Global Changes and Emergence of Infectious Diseases (M. E. Wilson, R. Levins \& A. Spielman, eds.), v. 740, pp. 13-23, New York: Annals of the New York Academy of Sciences.

GALLOPIN, G. C., 1994. Agroecosystem health: A guiding concept for agricultural research? In: International Workshop: Agriculture Health, Proceedings, pp. 51-65. Ottawa: University of Guelph/ International Development Research Centre.

GUNNING-SCHEPERS, L., 1989. The Health Benefits of Prevention: A Simulation Approach. Amsterdam: Elsevier.

HABERMAS, J., 1991. Modernity and Postmodernity. New German Critique, 22:3-14.

HODGSON, G. M., 1999. From Micro to Macro: The Concept of Emergence and the Role of Institutions. Paper presented at the international seminar on "Institutions and Economic Development: Towards a Comparative Perspective on State Reform", Rio de Janeiro, Brazil. (Version of June 8, 1999).

KAUFFMAN, S. A., 1993. The Origins of Order: Self-Organization and Selection in Evolution. Oxford/ New York: Oxford University Press.

LAKOFF, G. \& JOHNSON, M., 1980. Metaphors We Live By. Chicago: University of Chicago Press.
LEDERBERG, J. R. E.; SHOPE, R. \& OAKS, J. R., 1992. Emerging Infections: Microbial Threats to Health in the United States. Washington, D.C.: National Academy Press.

LEVINS, R., 1994. Natural Selection in Pathogens: In: Disease in Evolution: Global Changes and Emergence of Infectious Diseases (Wilson, M., Levins, R., Spielman, A., eds.), v. 740, pp. 260-270, New York: Annals of the New York Academy of Sciences.

LEVINS, R. \& LOPEZ, C. 1999. Toward an eco-social view of health. International Journal of Health Services, 29:261-293.

LEVINS, R.; AWERBUCH, T.; BRINKMAN, U.; ECKHARDT, I.; EPSTEIN, P.; FORD, T.; MAKHOUL, N.; POSSAS, C. A.; PUCCIA, C.; SPIELMAN, A. \& WILSON, M. E., 1993. Preparing for New Infectious Diseases. Harvard Working Group on New and Resurgent Diseases. Working Paper 8, Boston: Department of Population and International Health, Harvard School of Public Health.

LEVINS, R.; AWERBUCH, T.; BRINKMAN, U.; ECKHARDT, I.; EPSTEIN, P.; FORD, T.; MAKHOUL, N.; POSSAS, C. A.; PUCCIA, C.; SPIELMAN, A. \& WILSON, M. E., 1994. The emergence of new diseases. American Scientist, 82:52-60.

LEVINS, R.; AWERBUCH, T.; BRINKMAN, U.; ECKHARDT, I.; EPSTEIN, P.; FORD, T.; LEVINS, R.; MAKHOUL, N.; POSSAS, C. A.; PUCCIA, C.; SPIELMAN, A. \& WILSON, M. E., 1995. The new and resurgent diseases: The failure of attempted eradication. Ecologist, 25:21-26.

LEVINS, R.; AWERBUCH, T.; BRINKMAN, U.; ECKHARDT, I.; EPSTEIN, P.; FORD, T.; MAKHOUL, N.; POSSAS, C. A.; PUCCIA, C.; SPIELMAN, A. \& WILSON, M. E., 1996. Globalization, Development and the Spread of Diseases. In: The Case Against the Global Economy (J. Mander \& E. Goldsmith, eds.), pp. 161-170, New York: Sierra Club Books.

LYOTARD, J. F., 1984. The Postmodern Condition. Minneapolis: University of Minnesota Press.

LUTTWAK, E., 1999. Turbo Capitalism. New York: HarperCollins Publishers. 
McMULLAN, C., 1998. Indicators of Urban Ecosystem Health. Ottawa: International Development Research Centre.

MORIN, E., 1983. El Método: La Vida de la Vida. Madrid: Cátedra.

POSSAS, C. A., 1989. Epidemiologia e Sociedade: Heterogeneidade Estrutural e Saúde no Brasil. São Paulo: Editora Hucitec.

POSSAS, C. A., 1992. A sociological approach to epidemiological analysis: A tool for future scenarios in developing countries. Harvard School of Public Health, Research Paper 71. Boston: Takemi Program in International Health.

POSSAS, C. A. \& MARQUES, M. B., 1994. Health Transition and Complex Systems: a Challenge to Prediction? In: Disease in Evolution, Global Changes and Emergence of Infectious Diseases (M., Wilson, R., Levins \& A., Spielman, eds.), v. 740, pp. 285296, New York: Annals of the New York Academy of Sciences.

POSSAS, C. A., 1996. Drugs and vaccines in evolution for new and old diseases. In: Biosafety of Transgenic Organisms in Human Health Products (L. M. Oda, ed.), pp. 39-65, Rio de Janeiro: Editora Fiocruz.

POSSAS, C. A., 2000. Urbanização, ecologia e emergência de formas graves da leptospirose. In: Estado da Arte e Prioridades para Pesquisa e Desenvolvimento em Leptospirose (A. Homma \& C. A. Possas, org.), pp. 43-49, Rio de Janeiro: Vice-presidência de Tecnologia, Fundação Oswaldo Cruz.

PRIGOGINE, I. \& STENGERS, I., 1984. Order Out of Chaos: Man's New Dialogue with Nature. London: Heinemann.
PUCCIA, C. J.; AWERBUCH, T. \& LEVINS, R., 1994. Models for new and Resurgent Diseases. In: Disease in Evolution: Global Changes and Emergence of Infectious Diseases (Wilson, M., Levins, R., Spielman, A., eds.), v. 740: pp. 225-231, New York, Annals of the New York Academy of Sciences.

PUCCIA, C. J. \& LEVINS, R., 1986. Qualitative Modeling of Complex Systems: An Introduction to Loop Analysis and Time Averaging. Cambridge: Harvard University Press.

SILVEIRA, A. C., 1998. Febre amarela: Aspectos epidemiológicos e de controle. Revista da Sociedade Brasileira de Medicina Tropical, 31(Sup. 2):75-78.

SMIT, B. \& SMITHERS, J. 1994. Sustainable Agriculture and Agroecosystem Health. In: International Workshop: Agriculture Health, Proceedings, pp. 31-37, Ottawa: University of Guelph/International Development Research Centre.

SPASOFF, R. A. \& McDOWELL, I. W., 1987. Estimating the combined effect of several disease precursors in health risk appraisal. American Journal of Preventive Medicine, 3:182-189.

RAPPORT, D. J., 1989. What constitutes ecosystem health? Perspectives in Biology and Medicine, 33:120-132.

UNDP (United Nations Development Programme), 1999. Globalization with a Human Face. Human Development Report. Oxford: Oxford University Press.

UNEP (United Nations Environment Programme), 2000. Global Environment Outlook 2000. London: Earthscan Publications.

WALTNER-TOEWS, D., 1996. Ecosystem health: A framework for implementing sustainability in agriculture. Bioscience, 46:686-689.

WHITEHEAD, L., 1993. On reform of the state and regulation of the market. World Development, 21:1371-1393. 